contents relative to the Circumpolar Deep Water ${ }^{24}$. The reduction or cessation of NADW during glacial times would likely change the hydrographic characteristics of the deep water within the ACC, creating a Glacial Circumpolar Deep Water reflected by the Melonis-Uvigerina faunal assemblage. It seems unlikely that the Glacial Circumpolar Deep Water was a young, welloxygenated water mass formed in the Southern Ocean, since the $\mathrm{CaCO}_{3}$ record from E49-18 (ref. 10) shows glacial intervals to have low amounts of $\mathrm{CaCO}_{3}$ relative to the interglacial intervals. If deep-water formation was taking place, a young, well-oxygenated water mass would enhance $\mathrm{CaCO}_{3}$ preservation. Thus, the Glacial Circumpolar Deep Water was probably a modification of the present-day Circumpolar Deep Water.

A change in deep-water characteristics within the ACC probably affected the Southern Ocean heat budget. That a change in the Southern Ocean heat budget did occur is shown by the migration of the Polar Front ${ }^{25-27}$ and by the change in the extent of summer sea ice during glacial intervals. Summer sea ice during the last glacial interval is inferred to have extended to $55^{\circ} \mathrm{S}$ (ref. 28 ) in contrast to the present day when summer sea ice melts back to the Antarctic continent ${ }^{29}$. The lack of NADW in the ACC may have decreased deep-water temperatures, as the NADW is a source of warm water for the ACC in the present day. This cooling of deep water temperatures would have enhanced sea-ice formation and retarded summer sea-ice melting, because the warm Circumpolar Deep Water is considered important in providing heat for the melting of sea ice ${ }^{30}$.

The close correspondence between the bottom-water mass changes in the Southern Ocean and the Northern Hemisphere ice volume record suggests that bottom-water production in the Norwegian Sea and the amount of Northern Hemisphere ice are controlled by the same variables. For example, polar cooling would influence both the amount of Northern Hemisphere ice and the development of sea ice in the Norwegian Sea. An additional factor which may have influenced NADW production is Mediterranean Sea outflow water ${ }^{31}$, which flows westward from the Straits of Gibraltar ${ }^{23}$. Reid ${ }^{31}$ has suggested that Mediterranean outflow water also flows northwards into the Norwegian Sea, providing high-salinity water for the formation of Norwegian Sea overflow water. It was speculated that the elimination of Mediterranean outflow water caused by tectonic events at the sill or a drop in sea level closing the Straits of Gibraltar would preclude the formation of NADW, or alter its composition ${ }^{31}$. Following this argument, I speculate that the amount of Mediterranean outflow water during the Quaternary may be directly controlled by sea-level changes associated with Northern Hemisphere ice volume changes. For example, a lowering of sea-level, caused by a build-up of Northern Hemisphere ice, would decrease but would not eliminate the amount of Mediterranean outflow water to flow into the Norwegian Sea, which in turn would decrease the amount of Norwegian Sea overflow water produced.

I conclude that the benthic foraminiferal data from E49-18 show distinct glacial-interglacial oscillations which are interpreted to reflect significant changes in the Circumpolar Deep Water during the late Quaternary. The benthic foraminiferal faunal patterns in the Southern Ocean are similar to those found in the North Atlantic, and I suggest that the water mass changes within the $\mathrm{ACC}$ are a direct result of the reduction or elimination of NADW during glacial intervals. NADW production may be influenced not only by polar cooling, but also by sea-level regulated production of Mediterranean outflow water.

I thank E. A. Boyle, M. L. Bremer, C. D. Hollister, S. Honjo, L. D. Keigwin Jr, M. S. McCartney, and J. J. Morley for discussions; G. P. Lohmann for assistance with the principal component analysis; B. U. Haq, D. A. Johnson and L. D. Keigwin Jr for reviewing the manuscript; Dennis Cassidy for assistance in obtaining Eltanin samples; Stefan E. Masse for drafting and Frank Mederios for photographing the figures; E. Evans for typing the manuscript and Marleen $\mathrm{H}$. Jeglinski for technical assistance. This study was supported by NSF grant DPP-7821105 and DPP-8020479 (Division of Polar Programs)
This is Woods Hole Oceanographic Institution contribution no. 5118.

Received 15 March; accepted 28 May 1982.

1. Fandry, C. \& Pillsbury, R. D. J. phys. Oceanogr. 9, 449-455 (1979).

2. Streeter, S. S. Quat. Res. 3, 131-141 (1973).

Schnitker, D. Nature 248, 385-387 (1974).

4. Lohmann, G. P. J. Foram. Res. 8, 6-34 (1978).

5. Corliss, B. H. Mar, Geol. 31, 115-138 (1979).

6. Douglas, R. G. \& Heitman, H. L. Soc. Econ. Pal. Min., Spec. Pubt. 27, 231-246 (1979)

7. Buzas, M. A. \& Culver, S. J. Science 209, 687-689 (1980).

8. Culver, S. J. \& Buzas, M. A. Nature 290, 328-329 (1981).

9. Bremer, M. L. \& Lohmann, G. P. Deep-Sea Res. (in the press)

10. Hays, J. D., Imbrie, J. \& Shackleton, N. J. Science 194, 1121-1132 (1976)

11. Rodman, $M$. thesis, Columbia Univ. (1977)

12. Thierstein, H. R., Geitzenauer, K. R., Molfino, B. \& Shackleton, N. J. Geology 5, 400-404 (1979).

3. Morley, J. J. \& Shackleton, N. J. Geology 6, 309-311 (1978).

14. Corliss, B. H. Micropaleontology 25, 1-19 (1979).

15. Klovan, J. E. \& Imbrie, J. Int. Ass. math. Geol. J. 3, 61-78 (1971).

16. Corliss, B. H. Deep-Sea Res. (in the press)

17. Streeter, S. S. \& Shackleton, N. J. Science 203, 168-171 (1979).

18. Streeter, S. S. Geol. Soc. Am. Abstr. 9, 1192 (1977).

19. Schnitker, D. Mar. Micropaleont. 4, 265-280 (1979)

20. Kellogg, T. B. Boreas 9, 115-137 (1980).

21. Boyle, E. A. \& Keigwin, L. D. Jr EOS 63, 71-72 (1982)

22. Curry, W. B. \& Lohmann, G. P. EOS 62, 904 (1982)

23. Worthington, L. V. On the North Atlantic Circulation (The Johns Hopkins University Press, 1976).

44. Reid, J. L., Nowlin, W. D. Jr \& Patzert, W. C. J. phys. Oceanogr. 7, 62-91 (1977)

25. Climap Project Members Science 191, 1131-1137 (1976)

26. Williams, D. F. Mar. Micropaleont. 1, 363-375 (1976).

27. Morley, J. J. \& Hays, J. D. Quat. Res. 12, 396-408 (1979).

28. Hays, J. D., Lozano, J. A., Shackleton, N. J. \& Irving, G. Geol. Soc. Am. Mem. 145, $337-372$ (1976)

29. Fletcher, J. O. in National Science Foundation Memorandum R17-3793 (Santa Monica, 1969)

. 196 , 4193-4197 (1981).

31. Reid, J. G. Deep-Sea Res. 26A, 1199-1223 (1979).

\section{Historical evidence for a dramatic increase in the nitrate component of acid rain}

\section{P. Brimblecombe}

School of Environmental Sciences, University of East Anglia, Norwich NR4 7TJ, UK

\section{H. Stedman}

Atmospheric and Ocean Sciences, University of Michigan, Ann Arbor, Michigan 48109, USA

The concentrations of nitrate and ammonium ion in rainfall have an important effect on precipitation $p \mathrm{H}$. We have collected sets of rainfall analyses from non-urban sites in North America and western Europe, which start from last century, and we show here that there is a marked increase in the annual deposit of nitrate ion compared with relatively stable levels of ammonium ion deposit. The increase apparent in the data from the US parallels the increases in nitrogen oxide emissions from combustion processes and is large enough for the nitrate ion to contribute almost as much to the acidity of rainfall as the sulphate ion.

The best source of early rainfall analyses proves to be the records of agricultural stations concerned with the importance of meteoric nitrogen to crop yields. In the UK analyses were made at Rothamsted as early as 1853 , although $\mathrm{NO}_{3}^{-}$and $\mathrm{NH}_{3}$ were not determined simultaneously until several years later. In North America the earliest analyses appear in the 1880s. It is important to acknowledge the difficulties in assembling long records from sources widely separated by time and geography. There is some internal evidence in the Rothamsted data to suggest that even early analyses can be quite reliable ${ }^{1}$, and as large changes are to be expected they should be evident even in quite noisy data. An increase in the concentration of the nitrate ion in rainfall was suspected as long ago as 1918, and 
the principal source assumed to be combustion processes ${ }^{2}$. Ammonia, on the other hand, has long been considered to emanate largely from the soil ${ }^{3}$ and today the industrial inputs are relatively small ${ }^{4}$. Hence the annual deposit of the ammonium ion should have remained reasonably constant over the past $100 \mathrm{yr}$ Miller $^{5}$ tabulated some of the earlier data, collected from sites all over the world. As can be seen in Fig. 1 , the relative proportion of nitrogen as ammonia remains fairly constant, independent of locality and amount deposited. This pre-industrial value for the fraction of inorganic nitrogen present as the ammonium ion, $\mathrm{NH}_{4}^{+} /\left(\mathrm{NH}_{4}^{+}+\mathrm{NO}_{3}^{-}\right)$, of $\sim 0.7$ seems much reduced in present day North America and Europe, where values as low as half this are found. Such a change in the ratio would be expected if the nitrate ion concentration of precipitation were increasing and that of the ammonium ion remaining fairly constant.

Analytical records available for sites in eastern North America (including only one site outside the US, in Ottawa) and England and Benelux now cover a century, so annual deposits may be plotted as a function of time. Although analyses of rainfall composition have become more frequent recently, they are now often event or wet-only samples. Such results are

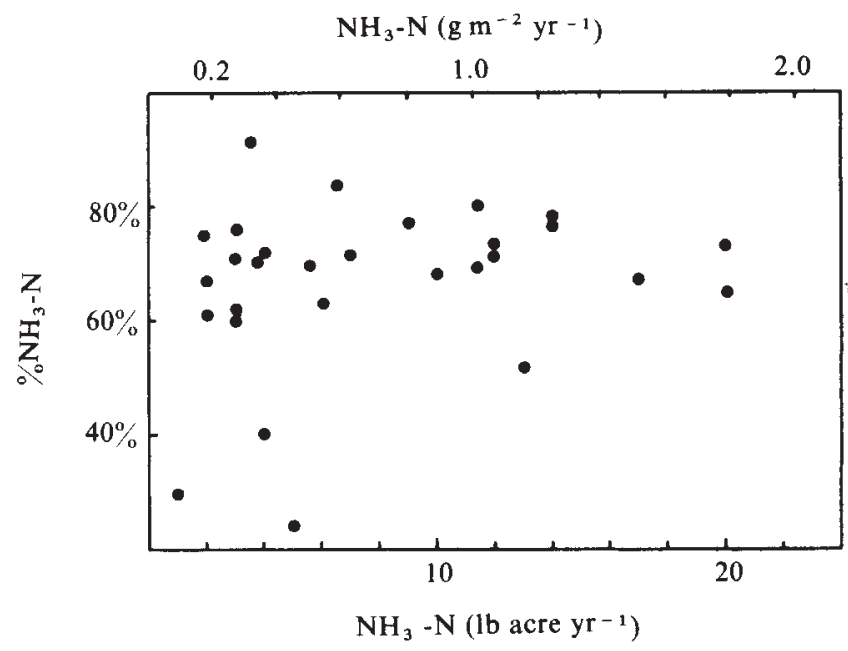

Fig. 1 The proportion of inorganic nitrogen deposited as ammonia as a function of ammonium ion deposit at sites in operation last century ${ }^{5}$.

difficult to compare with the older monthly samples which tend to show larger deposits (see ref. 6). Variation in the deposition of both nitrate and ammonium ion in the two regions are shown on semi-logarithmic axes in Figs 2 and 3. The annual values here are typically sums of 12 -monthly measurements. Gaps in the data for the period 1920-50 show a decline of interest in rainfall chemistry among agricultural researchers. In both regions the deposit of nitrate ion increases throughout the duration of the record, while the amount of deposited ammonium ion is stable. The deposit of nitrate-nitrogen in eastern North America may be compared with the combustion source strength of the oxides of nitrogen over the same period. The early $\mathrm{NO}_{x}$ emissions for the US were determined from the amounts of energy obtained from coal, wood, gas and petroleum combustion ${ }^{7}$, weighted for yields of $\mathrm{NO}_{x}$ (refs 8, 9). A small contribution of $0.015 \mathrm{~g} \mathrm{~m}^{-2} \mathrm{yr}^{-1}$ was estimated from burning due to forest clearance ${ }^{10}$ up to the year 1910 . The source strength (total emissions divided by area of the contiguous US) is plotted as a line in Fig. $2 a$ and agrees reasonably well with the observed changes. The location of England and Benelux about the North Sea does not allow such a simple calculation for the European data, but the display in Fig. 3 suggests the increase in nitrate deposition over the past $100 \mathrm{yr}$ is smaller in western Europe than in eastern North America.

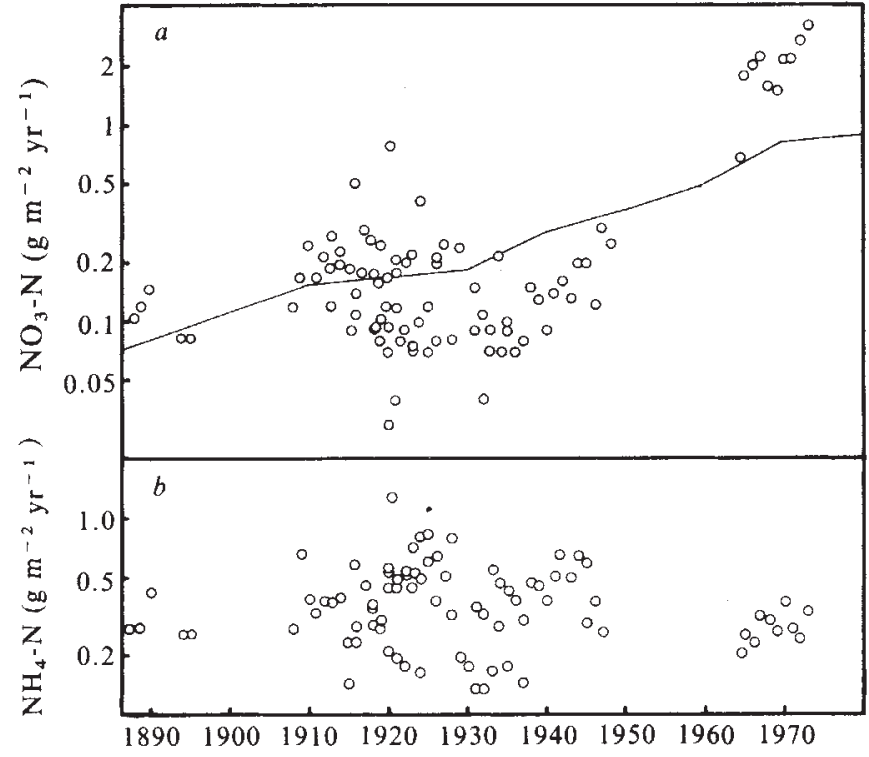

Fig. 2 Trends in the amount of nitrate $(a)$ and ammonium (b) ion brought down annually by rainfall in eastern North America. All but the most recent data come from agricultural sources ${ }^{17-26}$. The line plotted through the nitrate ion data indicates the estimate of the source strength for nitrogen as nitrogen oxides ${ }^{27,28}$. There may have been a slight change in precipitation amount over the past $100 \mathrm{yr}$, but this would probably be a decrease and certainly $<10 \%$ (ref. 29 ).

These changes and the fact that there is substantial agreement between emissions of oxides of nitrogen and the deposition in the US reaffirm that anthropogenic combustion is largely responsible for the observed changes. The anthropogenic contributions are thus so large that natural contributions to the nitrate ion concentrations in rainfall are presently almost negligible. This is in agreement with recently proposed global cycles $^{4,11}$, but is in conflict with the higher soil sources of $\mathrm{NO}_{x}$ adopted by earlier workers ${ }^{12,13}$. Charleson and Rodhe ${ }^{14}$ have recently noted how the lack of knowledge of the $\mathrm{HNO}_{3}$ cycle makes our understanding of the natural $p \mathrm{H}$ of rainfall difficult, but these results suggest that the levels of nitrate ion in US rainfall have now become greater than those of the ammonium ion, so that it can no longer neutralize the atmospheric nitric

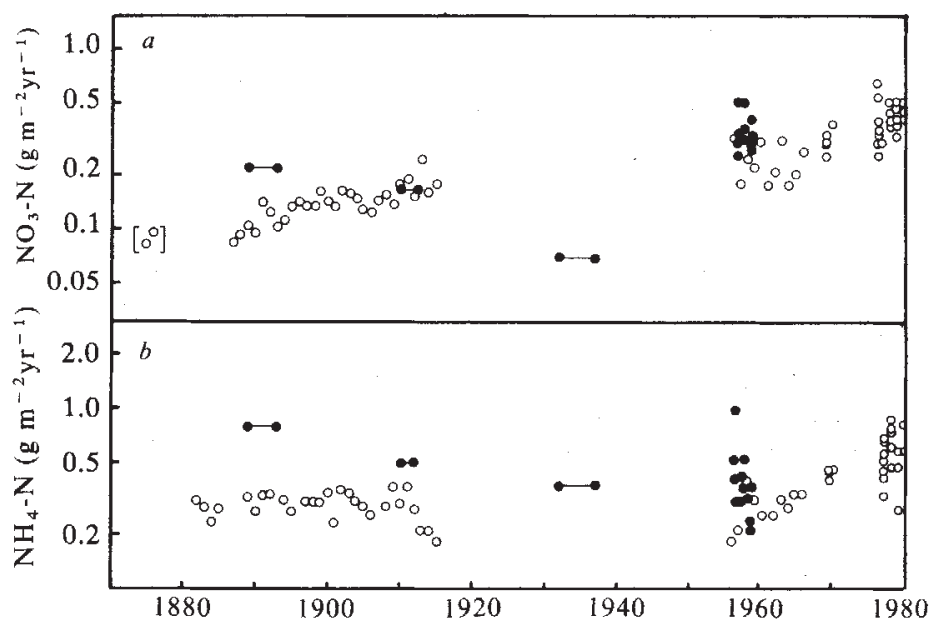

Fig. 3 Trends in the amount of nitrate $(a)$ and ammonium $(b)$ ion brought down annually in Belgium ${ }^{30,31}$, England ${ }^{2,5,15,30-34}$, and The Netherlands ${ }^{28,29}$. - Precipitation weighted annual means and the periods over which they are averaged. $O$, English data; continental data. The two bracketed points in the nitrate graph are displaced $20 \mathrm{yr}$ from 1855 to 1856 . The rainfall amount at Rothamsted shows. no obvious long-term trend over the past 100 yr (ref. 1). 
acid as it may have done in pre-industrial times. Figure $2 a$ implies an increase in nitrate ion deposition over eastern North America of $\sim 0.06$ equiv $\mathrm{m}^{-2} \mathrm{yr}^{-1}$ since 1880 . In regions receiving a $100-\mathrm{cm}$ annual precipitation this would imply a precipitation weighted mean $p_{\mathrm{H}}$ shift from 5.6 to about 4.2 in carbon dioxide equilibrated water. Note that the present day deposition

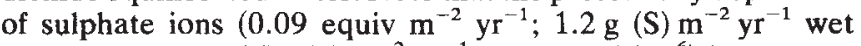
deposition and $0.25 \mathrm{~g}(\mathrm{~S}) \mathrm{m}^{-2} \mathrm{yr}^{-1}$ dry deposition ${ }^{6}$ ) is not very much larger than the current deposit of nitrate $\left(0.065\right.$ equiv $\left.\mathrm{m}^{-2} \mathrm{yr}^{-1}\right)$, reaffirming that the nitrate component of rain makes an important contribution to its acidity. Agricultural records do hint at an increase in sulphur deposition, but

Received 11 March; accepted 1 June 1982.

1. Brimblecombe, P. \& Pitman, J. I. Tellus 32, 261-267 (1980)

2. Russell, E. J. \& Richards, E. H. J. agric. Soc. 9, 309-337 (1919)

3. Liebig, J. Chemistry and its Applications to Agriculture and Physiology 3rd edn (Taylor and Walton, London, 1843).

4. Soderlund, R. \& Svensson, B. H. SCOPE 7, 27-73 (1976).

5. Miller, N. H. J. J. agric. Sci. 1, 280-303 (1905)

6. Galloway, J. N. \& Whelpdale, D. M. Atmos. Envir. 14, 409-417 (1980).

7. Hammond. A. L., Metz, W. D. \& Maugh, T. H. II Energy and the Future (American Association for the Advancement of Science, 1973)

8. Mulbhaier, J. L. in Solid Residential Fuels (eds. Cooper, J. A. \& Malek, D.) 164-187 (Oregon Graduate Centre, 1982).

9. Perkins, H. C. Air Pollution (McGraw-Hill, New York, 1974).

10. Wong, C. S. Science 200, 197-200 (1978),

11. Stedman, D. H. \& Shetter, R. E. Adv. Envir. Sci. Technol (in the press).

12. Robinson, E. \& Robbins, R. C. Air Pollut Control Ass. J. 20, 303 (1970).

13. Robinson, E. \& Robbins, R. C. in (ed. Singer, S. F.) The Changing Global Environment 50-64 (Springer, New York, 1970).

14. Charlson. R. J. \& Rodhe, H. Nature 295, 683-685 (1982)

15. Martin, A. \& Batber, F. R. CEGB (MR) Rural Rain Sampling Sites: Monihly Mean Concentration Values 1975-1980 (CEGB MID/SSD/81/0046/M, 1981). problems experienced in early analysis make these changes less clear than those for the nitrate and ammonium ion. The relative contribution of the nitrate and sulphate components of western European precipitation are different. In the English east Midlands, for example ${ }^{15}$, the deposits are: $\mathrm{NO}_{3}^{-}, 0.03 ; \mathrm{SO}_{4}^{2-}$, 0.055 equiv $\mathrm{m}^{-2} \mathrm{yr}^{-1}$, showing a slightly smaller contribution from the nitrogen component than in the North American observations. This difference might be expected from the differing patterns of fuel usage, as the number of equivalents provided by the $\mathrm{NO}_{x}$ component of the UK fuel emission is less than one-quarter of that derived from sulphur, while in the US it is about one-half. ${ }^{16}$

\section{Emissions of nitrous oxide from soils}

\section{J. M. Duxbury \& D. R. Bouldin}

Department of Agronomy, Cornell University, Ithaca, New York 14853, USA

\section{R. E. Terry* \& R. L. Tate III $\dagger$}

University of Florida, AREC Belle Glade, Florida 33430, USA

Potential changes in the concentration of nitrous oxide $\left(\mathrm{N}_{2} \mathrm{O}\right)$ in the atmosphere have sparked considerable interest because of the proposed role of $\mathrm{N}_{2} \mathrm{O}$ in regulating stratospheric ozone levels, and in contributing to the atmospheric greenhouse effect. A substantial portion of the atmospheric $\mathbf{N}_{2} \mathbf{O}$ is thought to result from microbial transformations of inorganic forms of nitrogen in soils; $\mathbf{N}_{2} \mathbf{O}$ is an intermediate in denitrification (reduction of $\mathrm{NO}_{3}^{-}$to $\mathrm{N}_{2}$ ) and is formed during nitrification (oxidation of $\mathrm{NH}_{4}^{+}$to $\mathrm{NO}_{3}^{-}$) in soils, although the mechanism is unclear. Several models have predicted that input of nitrogen into cropland, either from commercial fertilizers or $\mathbf{N}$-fixing leguminous crops, could sufficiently increase emissions of $\mathbf{N}_{2} \mathrm{O}$ from soils to deplete stratospheric ozone levels ${ }^{1-3}$ and raise average world temperatures ${ }^{4}$. We report here $\mathrm{N}_{2} \mathrm{O}$ emissions from mineral and organic soil sites in New York and from organic soil sites in the Florida Everglades Agricultural Area.

Only a few studies of emissions of $\mathrm{N}_{2} \mathrm{O}$ from soils have been carried out over extended time periods in commerical aricultural conditions. In the US Hutchinson and Mosier ${ }^{5}$ measured a loss of $2.6 \mathrm{~kg} \mathrm{~N}_{2} \mathrm{O}-\mathrm{N}$ ha ${ }^{-1}$ during corn growth in typical Colorado conditions and emissions of $\mathrm{N}_{2} \mathrm{O}$ ranging from 6 to $40 \mathrm{~kg} \mathrm{~N} \mathrm{ha}^{-1} \mathrm{yr}^{-1}$ have been reported for heavily fertilized, irrigated, vegetable fields in California ${ }^{6,7}$. Ryden found that $3.3 \mathrm{~kg} \mathrm{~N}_{2} \mathrm{O}-\mathrm{N} \mathrm{ha}^{-1} \mathrm{yr}^{-1}$ were evolved from fertilized perennial ryegrass in the $\mathrm{UK}^{8}$. These data exceed the Council for Agricultural Science and Technology's (CAST) estimated average value for cropland of $1 \mathrm{~kg} \mathrm{~N}_{2} \mathrm{O}-\mathrm{N} \mathrm{ha}^{-1} \mathrm{yr}^{-1}$ (ref. 9) and indicate the

Present addresses: *Depa tment of Agronomy, Brigham Young University, Provo, Utah 84602, USA; † Department of Soils and Crops, The State University of New Jersey, New Brunswick 08903, USA
16. Bach, W. Rev. Geophys. Space Phys. 14, 429-474 (1976).

17. Collinson R. \& Mensching J E New York St agric, exp. Stat. tech. Bull. No. 193 (1932)

18. Failyer, G. H. Willard, J. T. 2nd Ann. Rep. Kansas agric. Stat. 132-132 (1889).

19. Freeman, V. F. J. Am. Soc. Agron, 16, 356-8 (1924),

20. Likens, G. E. Biogeochemistry of a Forested Ecosystem (Springer, Berlin, 1977).

21. Mooers, C. A., McIntyre, W. H. \& Young, J. B. Univ. Tennessee agric. exp. Stat. Bull. No. $138(1927)$.

22. Shutt, F. T. Proc. Trans. R. Soc. Can, 4, 55-59 (1910)

23. Shutt, F. T. Proc. Trans. R. Soc. Can 8, 83-87(1914).

4. Shutt, F. T. \& Dorrance, R. L. Proc. Trans. R. Soc. Can. 11, 63-67, (1917)

25. Shutt, F. T. \& Medley, B. Proc. Trans. R. Soc. Can. 19, 1-10 (1925).

25. Shutt, F. T. \& Medley, B. Proc. Trans. R. Soc. Can. 19, 1
26. Wilson, B. D. J. Am. Soc. Agron. 18, 1208-1212 (1926).

27. Cavender, J. H., Kircher, D. S. \& Hoffman, A. J. US EPA Publ. No. AP-115 (1973).

28. Clark, T. L. Atmos. Envir. 14, 960-961 (1980).

29. Wahl, E. W. \& Lawson, T. L. Mon. Weath. Rev. 98, 259-265 (1970).

30. Tellus 8,112 (1956).

31. Erikson, E. Tellus 4, 215-232 (1952).

32. Jenkinson, D. S. Rothamsted Exptl Stat Rept. 1976, 103-109 (1977)

32. Jenkinson, D. S. Rothamsted Exptl Stat Rept. 1976, 103-109 (1977).

4. White, E., Starkey, R. S. \& Saunders, M. J. J. Appl. Ecol. 8, 743-749 (1971).

need for further assessment of emissions of $\mathrm{N}_{2} \mathrm{O}$ from agricultural fields.

Measurement of $\mathrm{N}_{2} \mathrm{O}$ flux from sites in New York and Florida was by a chamber method ${ }^{10}$. Sampling locations within a site were defined for extended periods of time by a metal rim $(60$ or $76 \mathrm{~cm}$ diameter) sunk 5 or $10 \mathrm{~cm}$ into the soil. When a flux measurement was to be made, a chamber was completed by sealing an insulated top to the rim with a wide rubber band cut from tire innertubes. Chamber volume was 28,56 , or 801 and tops were removed immediately after each flux measurement. Gas samples $(5$ or $10 \mathrm{ml})$ were withdrawn from the chamber at zero time and $10-\mathrm{min}$ intervals up to $30 \mathrm{~min}$ or at $30-\mathrm{min}$ intervals up to $1 \mathrm{~h}$, and their $\mathrm{N}_{2} \mathrm{O}$ contents were determined by gas chromatographic analysis using a ${ }^{63} \mathrm{Ni}$ electron capture detector ${ }^{10}$. Analytical precision was routinely $1 \%$ at the 1 p.p.m. level. Changes in concentration of $\mathrm{N}_{2} \mathrm{O}$ greater than 10 p.p.b. in $1 \mathrm{~h}(3 \%$ of ambient level, corresponding to a flux of about $0.5 \mathrm{~g} \mathrm{~N} \mathrm{ha}^{-1}$ day $^{-1}$ ) were considered significant. Frequency of flux measurement was based on the magnitude of observed fluxes and on environmental and management variables. Measurements were usually made daily during high flux periods.

Daily flux values were the mean of four or five simultaneous flux measurements from chambers spaced randomly $(5-10 \mathrm{~m}$ apart) over the site. The coefficient of variation (CV) for daily flux measurements ranged from 0 to $224 \%$, with means in the range $60-94 \%$ for New York and $43-56 \%$ in Florida. No relationship between flux magnitude and $\mathrm{CV}$ was found. Fluxes from individual chambers showed similar trends with time but were sometimes out of phase during high flux periods. Variability amongst chambers was consistently reduced when fluxes were summed over important flux periods, allowing significant effects of treatment and/or crop on $\mathrm{N}_{2} \mathrm{O}$ emissions to be demonstrated.

Mineral soil sites in New York were on silt loam soils. Alfalfa and field corn were grown following established practices for the northeastern US and an unmanaged timothy grass-mixed weed stand was included for comparative purposes. Only corn received fertilizer $\mathrm{N} ; 20 \mathrm{~kg} \mathrm{~N}^{-1}$ was applied to the seed bed at planting, but the major nitrogen supply came either from manure applied and ploughed down before planting $\left(C_{\mathrm{M}}\right)$ or from a sidedressing of commercial liquid fertilizer applied 40 days after planting $\left(C_{\mathrm{F}}\right)$. Annual emissions of $\mathrm{N}_{2} \mathrm{O}$ from 